\title{
Identification of biomarkers for the detection of subtle brain injury after cannabis and/or tramadol administration
}

\author{
Omar M. E. Abdel-Salam*, Amany A. Sleem², Eman R. Youness ${ }^{3}$ and Enayat A. Omara ${ }^{4}$
}

\begin{abstract}
Background: There is a need to identify biomarkers which could indicate the occurrence of brain injury in drug abuse. Objectives: We aimed to investigate ubiquitin-C-terminal hydrolase-1 (UCH-L1), a neuronal cell body injury marker, the glial protein S-100 beta (S100ß), and the glial fibrillary acidic protein (GFAP) as putative markers for neuronal injury due to cannabis, tramadol, or their combined use.

Materials and methods: Rats were treated with cannabis and/or tramadol subcutaneously daily for 6 weeks and UCH$L 1, S 100 \beta$, and GFAP were immunoassayed in the brain and serum.

Results: The results are as follows: (i) either cannabis or tramadol increased UCH-L1 and GFAP in the brain, (ii) serum UCH-L1 and GFAP increased by the highest dose of cannabis or tramadol, (iii) there was no additive effect for cannabis and tramadol on UCH-L1 or GFAP level in the brain or serum, (iv) S100ß decreased in the brain by $5-20 \mathrm{mg} / \mathrm{kg}$ of cannabis and in the serum following $20 \mathrm{mg} / \mathrm{kg}$ of cannabis, and (v) S100 $\beta$ levels increased in the brain after $20 \mathrm{mg} / \mathrm{kg}$ of tramadol but decreased the brain and serum after both cannabis and tramadol. Cytoplasmic vacuolations, apoptotic cells, and gliosis were observed in the brain tissue of cannabis and/or tramadol-treated rats.
\end{abstract}

Conclusions: These results suggest that changes in UCH-L1, GFAP, or S100 $\beta$ are likely to reflect neurotoxicity and serum levels could be used to detect neuronal damage in chronic users.

Keywords: Biomarkers, Cannabis, Tramadol, Brain injury

\section{Background}

Cannabis (marijuana) is the most common illicit substance used by adult and adolescent worldwide. Cannabis is driven from the female plant cannabis sativa that is rich in psychoactive delta-9-tetrahydrocannabinol $\left(\Delta^{9}\right.$ THC) (ElSohly et al. 2017). The United Nations Office on Drugs and Crime (UNODC) has estimated that 183 million people all over the world have used cannabis in 2014 (World drug report 2018). The use of cannabis is common especially during adolescence where the drug is usually perceived as innocent and there decreased awareness of its potential health consequences (AbdelSalam et al. 2017; Wadsworth and Hammond 2019). Research into the health hazards of cannabis, however,

\footnotetext{
* Correspondence: omasalam@hotmail.com

'Department of Toxicology and Narcotics, National Research Centre, Tahrir

St., Dokki, Cairo, Egypt

Full list of author information is available at the end of the article
}

revealed an association with poor academic achievement (Hooper et al. 2014), decline in cognitive function, working and short-term memory dysfunction (Solowij and Battisti 2008; Becker et al. 2010), and the propensity for developing psychosis (French et al. 2015). Cannabis use in adolescence appear to induce subtle changes in the adult brain circuits resulting in impaired emotional and cognitive performance and an increase in the vulnerability for other illicit drugs (Realini et al. 2009). There are also brain structural alterations in heavy users of cannabis (Lorenzetti et al. 2015).

Tramadol is another increasingly popular drug of abuse (Randall and Crane 2014; El-Hadidy and Helaly 2015), a centrally acting analgesic used worldwide for the treatment of moderate to severe pain in acute or chronic conditions. It is atypical synthetic opioid (4-phenylpiperidine analog of codeine) with selectivity for the $\mu$-opioid receptor (Grond and Sablotzki 2004). Little 
data exists as regards the neurotoxicity of tramadol, but an increase in deaths was, however, noted (Randall and Crane 2014) and high doses are associated with an increase in symptoms of anxiety, depression, and obsessive-compulsive neurosis as well as in hostile and aggressive behavior (El-Hadidy and Helaly 2015).

Users of cannabis are more likely to use other illicit drugs (Berge et al. 2014). Hence, the users of cannabis are also likely to use tramadol in addition. Studies on tramadol abuse among school students showed that $17 \%$ of users were using a combination of tramadol, alcohol, and cannabis (Bassiony et al. 2015). Students who were tramadol misusers reported using alcohol, cannabis, opium, ecstasy, and methamphetamine during the past month (Nazarzadeh et al. 2014).

Protein biomarkers are biological molecules present in brain cells that leak into the cerebrospinal fluid (CSF) or serum after injury to the brain cells (Laterza OF et al. 2008). Examples are the glial protein S-100 beta (S100 $\beta)$, glial fibrillary acidic protein (GFAP), and ubiquitin carboxy-terminal hydrolase (UCH-L1). S100 $\beta$ is the major low affinity calcium-binding protein in astrocytes and is considered a marker of astrocyte activation, injury, or death (Roberts et al. 2015). Ubiquitin-C-terminal hydrolase-1 is abundant in neuronal cell body and is involved in the removal of excessive, oxidized, or misfolded proteins during both normal and pathological conditions (Gong and Leznik 2007). Glial fibrillary acidic protein (GFAP) is a major protein constituent of glial filaments in astrocytes which is important in cytoskeleton support and is considered a useful marker for brain damage (Yang and Wang 2015).

Studies have indicated the importance of these protein biomarkers in monitoring brain damage and outcomes in patients with traumatic brain injury (Lewis et al. 2017; Ramezani et al. 2018) or concussion (Mannix et al. 2014). In this context, it has been that measurements of serum/ plasma levels of UCH-L1 can predict head CT findings (Ramezani et al. 2018). It was also found that serum concentrations of UCH-L1, GFAP, or S-100 $\beta$ within $6 \mathrm{~h}$ of head injury are of value in estimating the severity of brain injury after head trauma (Lewis et al. 2017).

On the other hand, little data exists as regards the utility of these protein biomarkers in neurotoxicity studies. Thus, UCH-L1 and GFAP were shown to increase in CSF and in brain following kainic acid-induced excitotoxicity and neurodegeneration in rats (Glushakova et al. 2012) while $S 100 \beta$ increased in plasma in response to the organophosphorus compound deltamethrin (Patro et al. 2009) and different anesthetic agents (Xu et al. 2015). S100 $\beta$, UCH-L1, and GFAP could thus be useful markers of neurotoxicity.

The present study was therefore designed to investigate whether the changes in the level of S100 $\beta, \mathrm{UCH}-\mathrm{L} 1$, or GFAP proteins in serum would reflect neurotoxicity induced by cannabis and/or tramadol and thus could be used to monitor neuronal damage in chronic users of these substances of abuse.

\section{Materials and methods \\ Animals}

Adult male Sprague-Dawley rats (weighing 130-140 g) were included in this study. Rats were purchased from the animal house of the National Research Centre (NRC). Animals were housed under standardized housing conditions with room temperature of $24-27{ }^{\circ} \mathrm{C}$ and humidity of $60 \%$ and alternating 12 -h light and dark cycles. Rats were allowed free access to standard laboratory pellets and water.

\section{Drugs and chemicals}

Tramadol and the Cannabis sativa plant were a gift from the Ministry of Justice (Egypt). Tramadol was dissolved in saline and subcutaneously administered. Other reagents and chemicals were purchased from Sigma (St. Louis, USA).

\section{Cannabis extract}

Cannabis sativa extract was prepared from the plant's flowering tops and leaves after drying. The extraction method was that described by Turner and Mahlberg (1984) with modification. In brief, $10 \mathrm{~g}$ of the dried plant material was ground with a mortar and pestle. Decarboxylation of the plant material was accomplished by placing the material in a glass test tube, covered with aluminum foil, and subjecting it to heat $\left(100{ }^{\circ} \mathrm{C}\right)$ in an oven for $2 \mathrm{~h}$. Thereafter, $10 \mathrm{ml}$ of chloroform (analytical grade) was added and left to react overnight. The cannabis material was extracted three times. Fractions were then combined, filtered over a filter paper, and collected. Evaporation of the filtrate was done by a gentle stream of nitrogen on ice and protected from light. The residue was stored at $4{ }^{\circ} \mathrm{C}$ and protected from light using an aluminum-covered container. For the experiments, the residue was re-suspended in $2 \mathrm{ml}$ of $96 \%$ ethanol, and the total volume increased to $100 \mathrm{~mL}$ by the addition of saline. $\Delta^{9}$-THC content of the cannabis extract was quantified using gas chromatography-mass spectrometry and found to be $\sim 10 \%$.

\section{Experimental design}

Different groups of rats ( $n=6$ each) were used. Rats were randomly assigned to treatment groups as follows:

a. Group 1 received the vehicle $(0.2 \mathrm{ml}$ saline $)$ daily.

b. Groups 2, 3, and 4 received cannabis $(5,10$, and 20 $\mathrm{mg} / \mathrm{kg}$ : equivalent to the active constituent $\Delta^{9}$ tetrahydrocannabinol). 
c. Groups 5, 6, and 7 received tramadol $(5,10$, and 20 $\mathrm{mg} / \mathrm{kg}$ ).

d. Groups 8, 9, and 10 received tramadol $(10 \mathrm{mg} / \mathrm{kg})$ in combination with cannabis $(5,10$, or $20 \mathrm{mg} / \mathrm{kg})$.

Drugs were administered subcutaneously daily for 6 weeks. We used the subcutaneous route of administration for ensuring good absorption, and this route of application as well as the doses was used in other studies on cannabis and tramadol (Abdel-Salam et al. 2014; Abdel-Salam et al. 2016). The animals were subsequently sacrificed by decapitation. The whole brain of each rat was rapidly removed out and snap-frozen in liquid nitrogen. Brain tissue samples were stored at $-80{ }^{\circ} \mathrm{C}$ until further processing. Frozen samples were thawed and homogenized in a glass tube with a Teflon dounce pestle in ice-cold phosphate buffer solution $(50 \mathrm{mM}$ Tris- $\mathrm{HCl}$, $\mathrm{pH}$ 7.4) and sonicated. Homogenized samples were then centrifuged at $9000 \mathrm{~g}$ for $5 \mathrm{~min}$ at $4{ }^{\circ} \mathrm{C}$. The supernatant was stored at $-80^{\circ} \mathrm{C}$ until further analysis.

The histopathological study was carried out on separate groups of rats ( $n=5$ per group) that received cannabis, tramadol, or their combination. The groups which were subjected to pathological investigations ran parallel to and followed the same experimental course as rats subjected to measuring their serum biomarkers.

\section{ELISA for quantification of S100 $\beta$, UCHL-1, and GFAP}

Brain homogenates and serum were analyzed for $S 100 \beta$ and UCHL-1, and GFAP using enzyme-linked immunosorbent assay (ELISA) kit from Glory Science Co., Ltd. (Del Rio, USA) according to the manufacturer's instructions. The ELISA Assay Kit is based on binding of S100ß, GFAP, or UCHL-1 by two antibodies, one immobilized on microwell plates, and the other one conjugated with horseradish peroxidase (HRP). The assay is a two-step binding procedure, and after every incubation step, the bound/free separation is performed by a simple solid-phase washing. Then, the enzyme HRP in the bound fraction reacts with the substrate $\left(\mathrm{H}_{2} \mathrm{O}_{2}\right)$ and the TMB substrate and develops a blue color that changes into yellow when the stop solution $\left(\mathrm{H}_{2} \mathrm{SO}_{4}\right)$ is added and the color change is measured at a wavelength of $450 \mathrm{~nm}$. The color intensity is proportional to the S100 $\beta$, GFAP, or UCHL-1 concentration in the sample. A standard curve is constructed by plotting absorbance values against concentrations of standards, and concentrations of S100 $\beta$, GFAP, or UCHL-1 in unknown samples are determined using this standard curve.

\section{Histopathological study}

Brain samples were fixed in $10 \%$ neutral-buffered formalin saline for at least $72 \mathrm{~h}$. Specimens were washed in $50 \%$ alcohol, dehydrated in ascending grades of alcohol, then cleared in xylene, and finally embedded in paraffin. Sections of $5 \mu \mathrm{m}$ thickness were stained with hematoxylin and eosin (H\&E) for histopathological examination using a light microscope (Drury and Walligton 1980). Images were examined and photographed under a digital camera (Microscope Digital Camera DP70, Tokyo) and processed using Adobe Photoshop version 8.0.

\section{Statistical analysis}

All results are expressed as mean \pm SE. Statistical significance was determined using an ANOVA, followed by Duncan's multiple range test using SPSS software, version 14 (SAS Institute Inc., Cary, NC). A probability value of less than 0.05 was considered statistically significant.

\section{Results}

Ubiquitin C-terminal hydrolase L1

Brain protein levels of UCH-L1 were significantly increased after cannabis $(5,10$, or $20 \mathrm{mg} / \mathrm{kg})$, tramadol $(5$, 10 , or $20 \mathrm{mg} / \mathrm{kg}$ ) or both cannabis and tramadol administration compared to the saline control group. The effect of cannabis, however, was not dose-dependent (Fig. 1a). Serum UCH-L1 was also significantly increased after $20 \mathrm{mg} / \mathrm{kg}$ of cannabis or $10-20 \mathrm{mg} / \mathrm{kg}$ of tramadol compared to the saline control group (Fig. 1b). UCH-L1 in the serum of rats treated with both cannabis and tramadol was also significantly raised compared to saline control values. UCH-L1 levels of were, however, not higher in the cannabis-tramadol combination treatment compared to treatment with only cannabis or tramadol (Fig. 1a, b; Table 1).

\section{Glial fibrillary acidic protein}

Significant increases in brain levels of GFAP were observed after treatment with $10-20 \mathrm{mg} / \mathrm{kg}$ of cannabis, $10-20 \mathrm{mg} / \mathrm{kg}$ of tramadol, or both cannabis and tramadol compared to the saline treated group. Serum levels of GFAP were also significantly increased in rats treated with either $20 \mathrm{mg} / \mathrm{kg}$ of cannabis, $20 \mathrm{mg} / \mathrm{kg}$ of tramadol, or both $10-20 \mathrm{mg} / \mathrm{kg}$ of cannabis and tramadol compared to the saline-treated group. The combination of cannabis/tramadol, however, did not result in significantly higher GFAP levels compared with either agent alone (Fig. 2a, b) (Table 2).

\section{S-100ß}

S100 $\beta$ levels in the brain were significantly decreased in cannabis $(5,10$, or $20 \mathrm{mg} / \mathrm{kg})$-treated rats compared to their saline-treated counterparts. The effect of cannabis, however, was not dose-dependent. Brain S100 $\beta$ was significantly increased after the highest dose of tramadol compared to the saline control value (Fig. 3a). The level 


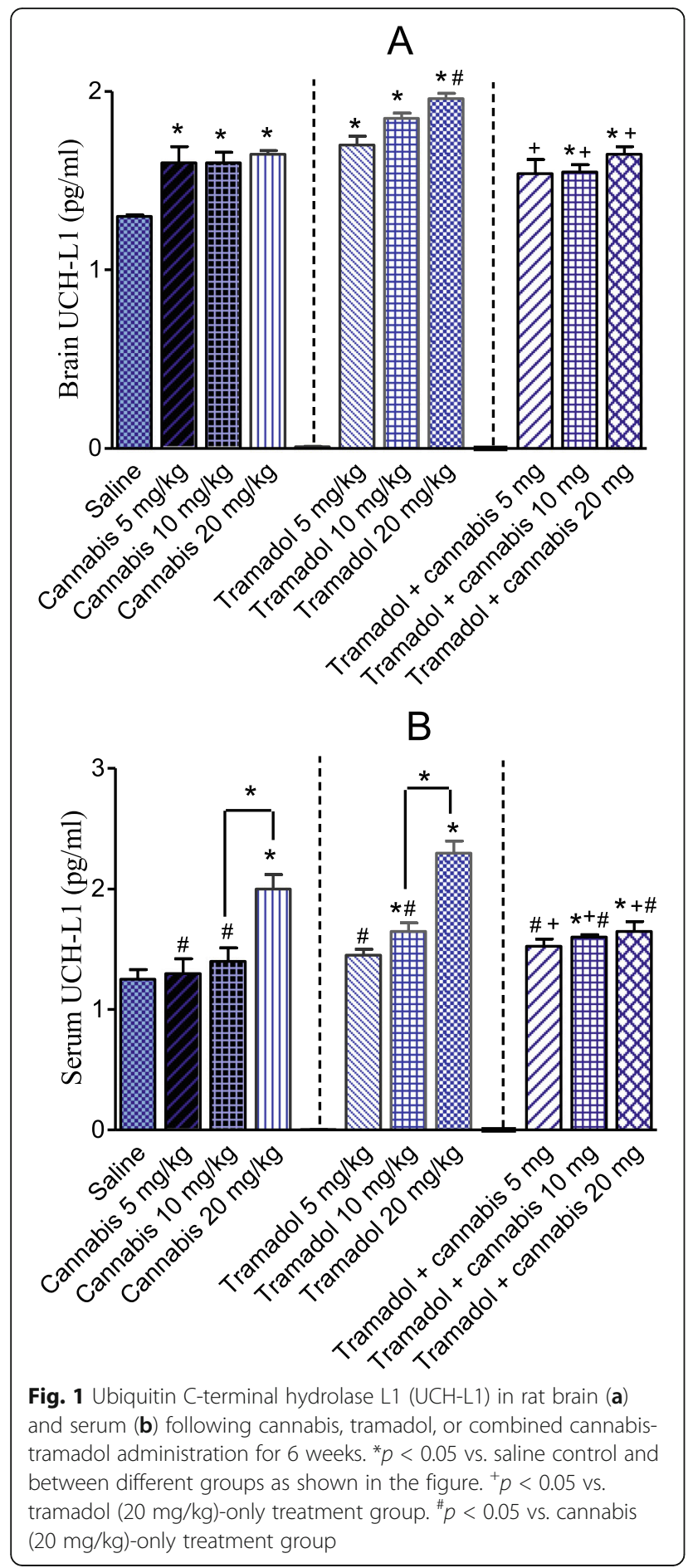

of $\mathrm{S} 100 \beta$ in the brain significantly decreased by the cannabis/tramadol combination compared to the salinetreated group (Fig. 3a). S100 $\beta$ was also significantly decreased in serum after $20 \mathrm{mg} / \mathrm{kg}$ of cannabis compared to saline control value. Meanwhile, S100 $\beta$ in serum significantly decreased in $20 \mathrm{mg} / \mathrm{kg}$ of tramadol-treated rats compared with saline control value (Fig. 3b). Serum
S100 $\beta$ was also significantly decreased in tramadol + cannabis $20 \mathrm{mg} / \mathrm{kg}$-treated rats compared to the salinetreated group (Fig. 3b, Table 3).

\section{Histopathological results}

Cerebral cortex

Sections from control rats showed neurons with normal appearance (Fig. 4a). Minimal or no changes were observed after treatment with cannabis at $5 \mathrm{mg} / \mathrm{kg}$ (Fig. 4b). Higher doses were associated with apoptotic neurons, pyknotic nuclei, and focal gliosis (Fig. 4c, d). Rats treated with tramadol $5 \mathrm{mg} / \mathrm{kg}$ showed shrunken neurons with dark cytoplasm and pyknotic nuclei (Fig. 4e). With higher doses, neurons lost their normal shape and appeared with indistinct boundaries. Irregular damaged cells with condensed, pyknotic, and apoptotic nuclei were seen. Perivascular space increased or dilated along with hemorrhage inside the brain parenchyma with diffuse gliosis and pericellular edema (Fig. 4f, g). Less severe degenerative changes were observed after treatment with tramadol $10 \mathrm{mg} / \mathrm{kg}$ and cannabis (5 or 10 $\mathrm{mg} / \mathrm{kg}$ ) (Fig. 4h, i). Rats treated with tramadol $10 \mathrm{mg} /$ $\mathrm{kg}$ and cannabis $20 \mathrm{mg} / \mathrm{kg}$ showed cytoplasmic vacuolations, pyknotic darkly stained nuclei, hemorrhage, and focal gliosis (Fig. 4j).

\section{Striatum}

Sections from control rats showed neurons with normal appearance (Fig. 5a). Cannabis (5 mg/kg)-treated rats exhibited no or minimal changes (Fig. 5b). Cannabis given at $10 \mathrm{mg} / \mathrm{kg}$ resulted in slight neuronal degeneration with few apoptotic neurons and pyknotic nuclei (Fig. 5c). However, cannabis given at $20 \mathrm{mg} / \mathrm{kg}$ caused mild neuronal degeneration with apoptotic neurons and pyknotic nuclei with gliosis (Fig. 5d). The administration of tramadol caused neurodegenerative changes with pyknotic, apoptotic nuclei, vacuolation of neuropil, and congested vascular channels. There was evidence of chromatin condensation and cytoplasmic shrinkage in the striatal neurons of tramadol-treated animals and necrosis with diffuse gliosis (Fig. 5e-g). Less degenerative changes were observed after treatment with tramadol $10 \mathrm{mg} / \mathrm{kg}$ and cannabis at $5 \mathrm{or} 10 \mathrm{mg} / \mathrm{kg}$ (Fig. $5 \mathrm{~h}$, i). However, treatment with tramadol $10 \mathrm{mg} / \mathrm{kg}$ and cannabis $20 \mathrm{mg} / \mathrm{kg}$ caused degenerative changes with focal gliosis (Fig. 5j).

\section{Discussion}

Cannabis and tramadol are two commonly abused substances. These are perceived as an innocent and subtle brain injury will go unnoticed. The objective of this study was to examine ubiquitin C-terminal hydrolase L1 (UCH-L1), glial fibrillary acidic protein (GFAP), and S100 beta $(\mathrm{S} 100 \beta)$ as potential biomarkers for subtle brain 
Table 1 Brain and plasma UCH-L1 in cannabis- and/or tramadol-treated rats

\begin{tabular}{lll}
\hline Treatment group & Brain UCH-L1 & Serum UCH-L1 \\
\hline Normal control & $1.30 \pm 0.01$ & $1.25 \pm 0.08$ \\
Cannabis $5 \mathrm{mg} / \mathrm{kg}$ & $1.60 \pm 0.09^{*}$ & $1.30 \pm 0.12^{\#}$ \\
Cannabis $10 \mathrm{mg} / \mathrm{kg}$ & $1.60 \pm 0.06^{*}$ & $1.40 \pm 0.11^{\#}$ \\
Cannabis $20 \mathrm{mg} / \mathrm{kg}$ & $1.65 \pm 0.02^{*}$ & $2.00 \pm 0.12^{*}$ \\
Tramadol $5 \mathrm{mg} / \mathrm{kg}$ & $1.70 \pm 0.05^{*}$ & $1.45 \pm 0.05^{\#}$ \\
Tramadol $10 \mathrm{mg} / \mathrm{kg}$ & $1.85 \pm 0.03^{*}$ & $1.65 \pm 0.07^{* \#}$ \\
Tramadol $20 \mathrm{mg} / \mathrm{kg}$ & $1.96 \pm 0.03^{* \#}$ & $2.30 \pm 0.10^{*}$ \\
Tramadol $10 \mathrm{mg} / \mathrm{kg}+$ cannabis $5 \mathrm{mg} / \mathrm{kg}$ & $1.54 \pm 0.08^{+}$ & $1.525 \pm 0.06^{+\#}$ \\
Tramadol $10 \mathrm{mg} / \mathrm{kg}+$ cannabis $10 \mathrm{mg} / \mathrm{kg}$ & $1.55 \pm 0.04^{*+}$ & $1.60 \pm 0.02^{*+\#}$ \\
Tramadol $10 \mathrm{mg} / \mathrm{kg}+$ cannabis $20 \mathrm{mg} / \mathrm{kg}$ & $1.65 \pm 0.04^{*+}$ & $1.65 \pm 0.08^{*+\#}$
\end{tabular}

Units for UCH-L1, pg/ml. ${ }^{*} p<0.05$ vs. saline control. ${ }^{+} p<0.05$ vs. tramadol $(20 \mathrm{mg} / \mathrm{kg})$-only treated group. ${ }^{*} p<0.05$ vs. cannabis $(20 \mathrm{mg} / \mathrm{kg})$-only treated group. Multiple group comparison was done using one-way ANOVA and post hoc Duncan's multiple range test. A probability value of less than 0.05 was considered statistically significant

injury due to repeated administration of cannabis and/or tramadol. Rats were treated with different doses of cannabis, tramadol, or both daily for 6 weeks and UCH-L1, S100 $\beta$, and GFAP were immunoassayed in the brain and serum. Brain histopathological studies were also done. Results indicated increased UCH-L1 and GFAP after cannabis and/or tramadol and in brain S100 $\beta$ after 20 $\mathrm{mg} / \mathrm{kg}$ of tramadol. Histopathological studies indicated the development of neuronal injury by either drug or their combined administration in a dose-dependent manner.

Our data show that UCH-L1 and GFAP proteins increased in the brain and serum after cannabis and/or tramadol administration. UCH-L1 is abundant in neuronal cell body and increased release of this protein in CSF or serum therefore reflects neuronal damage (Roberts et al. 2015). GFAP is a marker of reactive gliosis where brain injury results in microglia and astroglia being activated with increased GFAP expression. The measurement of GFAP released during astrocytosis and astroglial disintegration can be used to monitor glial pathology (O'Callaghan and Sriram 2005). Microglia and astrocytes express cannabinoid receptors (Stella 2010) and consequently respond to ligands for these receptors. In this context, subchronic administration of $\Delta^{9}$-THC in mice have shown to result in activation of cerebellar microglia and increased expression of the proinflammatory cytokine interleukin-1 $\beta$ (IL-1 $\beta$ ) (Cutando et al. 2013). Rats chronically treated with THC during adolescence showed increased GFAP staining in the hippocampus and parietal cortex (Lopez-Rodriguez et al. 2014). Studies in pre- and perinatal suggested that exposure to $\Delta^{9}$-THC accelerates the maturation of astrocytes in female rats but delays astrocytic maturation in males as determined by GFAP immunoreactivity in the substantia nigra (Suárez et al. 2000). In this study, in contrast to the effect of cannabis on brain GFAP, there was no dose-response effect for cannabis and on brain UCHL1 level, possibly reflecting rapid export of the biomarker out of the brain. Meanwhile, the increase in serum levels UCH-L1 and GFAP observed in the current study suggests leak of these proteins following neuronal injury.

We have also shown that $\mathrm{S} 100 \beta$ levels decreased in the brain by cannabis and cannabis/tramadol cotreatment. The decrease in brain $S 100 \beta$ by cannabis, however, was not dose-dependent. S100 $\beta$ decreased in the serum by the highest dose of either cannabis or tramadol and by tramadol-cannabis $20 \mathrm{mg} / \mathrm{kg}$. S100ß, however, increased in the brain after $20 \mathrm{mg} / \mathrm{kg}$ of tramadol. S100 $\beta$ is present in high concentration in astrocytes and thus is considered a marker of astrocyte activation, damage, or death (Roberts et al. 2015). It is increased in CSF, plasma, and brain of rodents following a number of neurotoxicants (Züngün et al. 2013; $\mathrm{Xu}$ et al. 2015) and is thus a useful marker of neurotoxicity. The increase in $S 100 \beta$ protein in the brain by the highest dose of tramadol probably reflects a drug neurotoxic effect. This, however, contrasts with the decline in serum S100 $\beta$ following cannabis, tramadol, and both cannabis and tramadol administration. This finding is intriguing in view of the ability of cannabis to induce neuronal damage as observed on histopathological examination of brain tissue sections. Cannabis mediates its effects on the brain by interacting with cannabinoid CB1 receptors, with $\Delta^{9}$-THC being the cannabinoid mostly implicated (ElSohly et al. 2017). Cannabis or $\Delta^{9}$ THC has been shown to modulate cytokine release from tissue macrophages, inhibiting tumor necrosis factor-alpha (TNF- $\alpha$ ) (Zheng and Specter 1996) and stimulating interleukin-1beta (Il-1 $\beta$ ) release (Shivers et al. 1994), and it is thus possible that $\Delta^{9}$-THC inhibits $\mathrm{S} 100 \beta$ release from astrocytes. In support of this notion, the finding that the endocannabinoid and $\mathrm{CB} 1$ receptor 


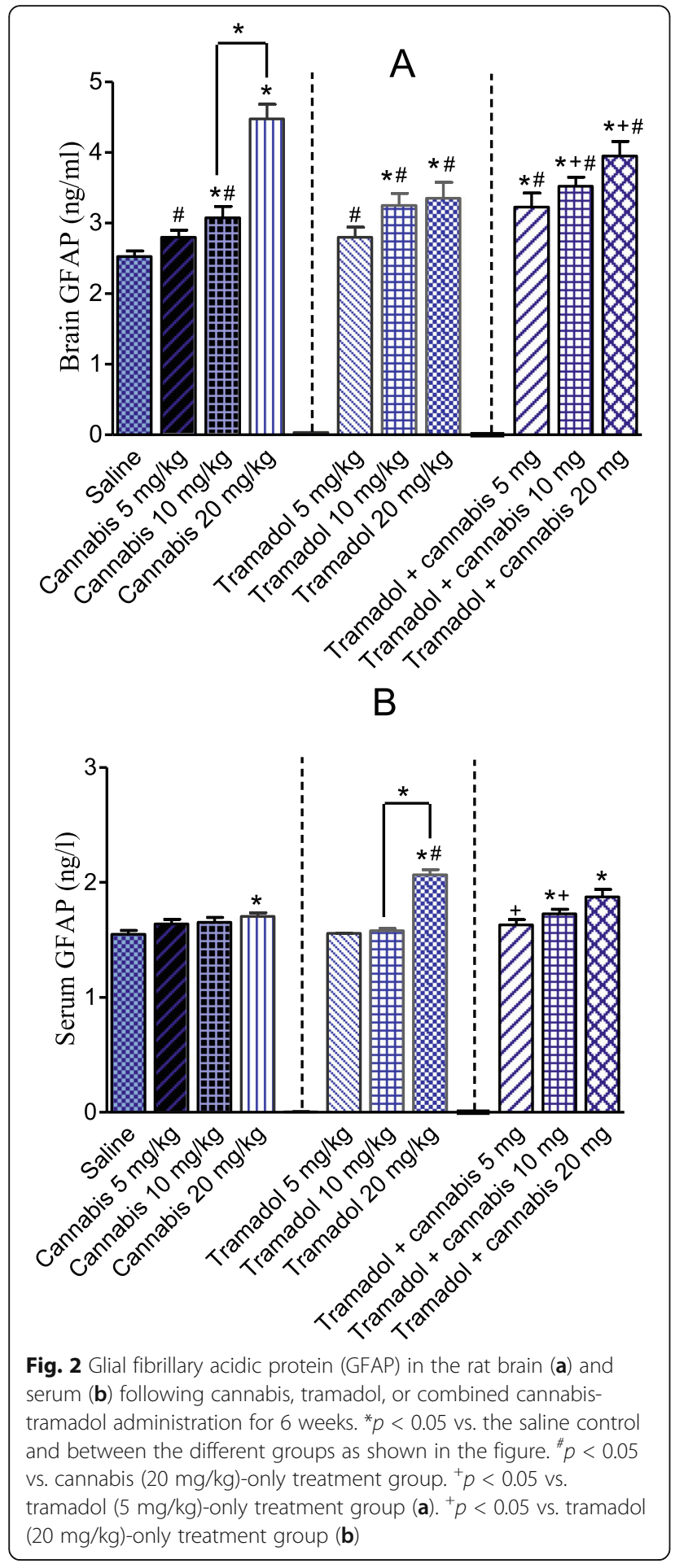

agonist arachidonyl-2-chloroethylamide was able to inhibit the increased S100 $\beta$ density induced in glial cells by a dopaminergic neurotoxin (Iuvone et al. 2007).

S100 $\beta$ has been shown to exert neurotrophic or neurotoxic effects depending on its concentration, exerting trophic effects and increasing neuronal survival at nanomolar concentrations (Kögel et al. 2004; Villarreal et al.

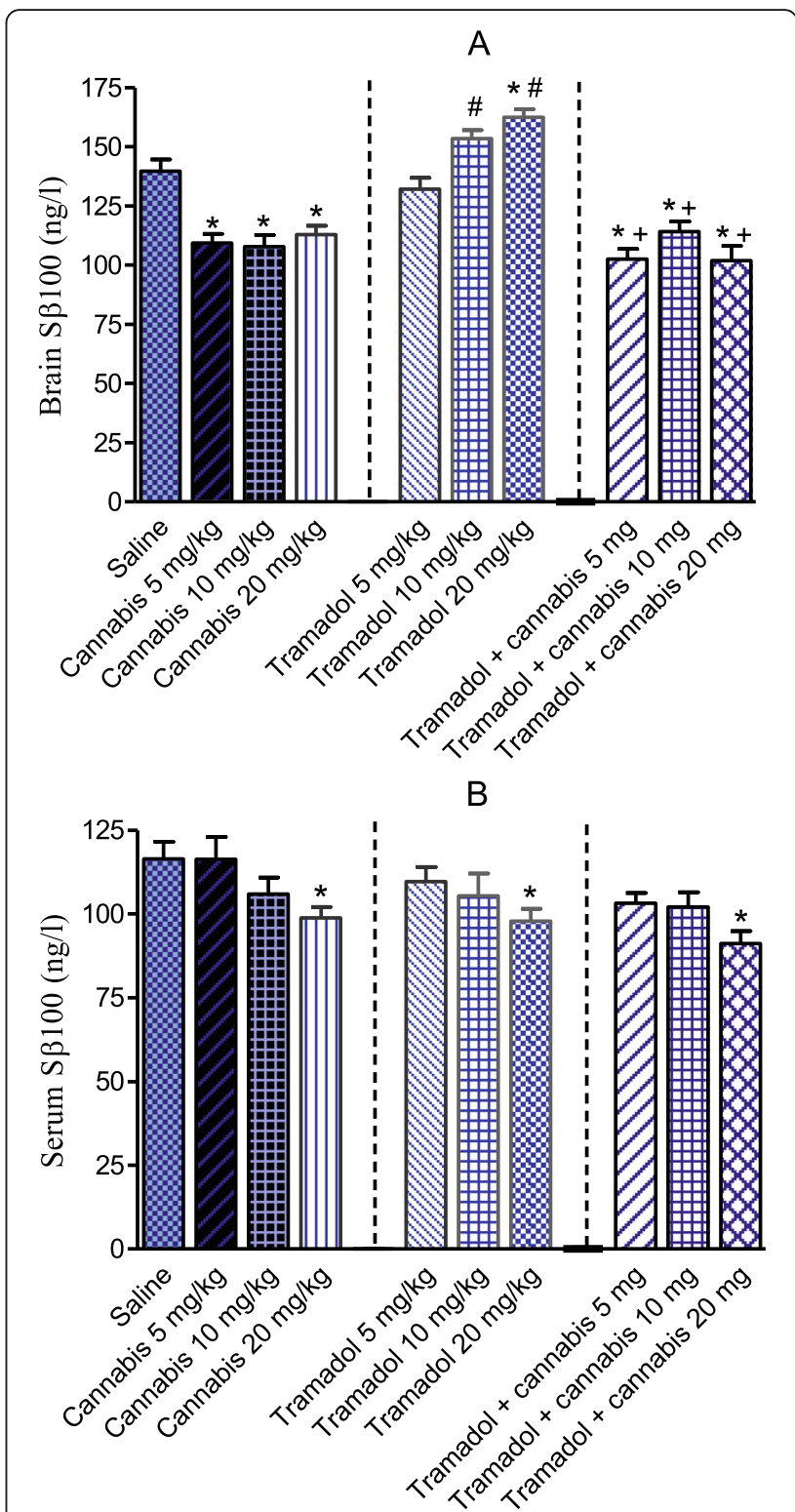

Fig. 3 Glial protein S-100 beta (S100ß) in rat brain (a) and serum (b) following cannabis, tramadol, or combined cannabis-tramadol administration for 6 weeks. ${ }^{*} p<0.05$ vs. the saline control ${ }^{+} p<0.05$ vs. corresponding tramadol-only treatment group. ${ }^{\#} p<0.05$ vs. cannabis (20 mg/kg)-only treatment group

2011) but is detrimental to neurons at the micromolar level (Villarreal et al. 2011; Reali et al. 2012). S-100ßoverexpressing transgenic mice showed increased glial activation, neuroinflammation, and increased neuronal damage in response to $A \beta$ peptide (Craft et al. 2005). $\mathrm{S} 100 \beta$ activates nuclear factor-kappaB (NF- $\mathrm{kB})$, and increases Il-1 $\beta$ mRNA levels in primary microglia cells, and in primary cortical neurons (Liu et al. 2005), stimulates nitric oxide release from microglia (Adami et al. 2004), astrocytes (Ponath et al. 2007) and stimulates IL6 and TNF- $\alpha$ secretion in cultured astrocytes (Ponath 
Table 2 The brain and plasma GFAP in cannabis- and/or tramadol-treated rats

\begin{tabular}{llc}
\hline Treatment group & Brain GFAP & Serum GFAP \\
\hline Normal control & $2.525 \pm 0.08$ & $1.55 \pm 0.03$ \\
Cannabis $5 \mathrm{mg} / \mathrm{kg}$ & $2.80 \pm 0.10^{\#}$ & $1.64 \pm 0.03$ \\
Cannabis $10 \mathrm{mg} / \mathrm{kg}$ & $3.075 \pm 0.16^{* \#}$ & $1.655 \pm 0.04$ \\
Cannabis $20 \mathrm{mg} / \mathrm{kg}$ & $4.475 \pm 0.21^{*}$ & $1.705 \pm 0.03^{*}$ \\
Tramadol $5 \mathrm{mg} / \mathrm{kg}$ & $2.80 \pm 0.14^{\#}$ & $1.557 \pm 0.001$ \\
Tramadol $10 \mathrm{mg} / \mathrm{kg}$ & $3.25 \pm 0.17^{* \#}$ & $1.58 \pm 0.02$ \\
Tramadol $20 \mathrm{mg} / \mathrm{kg}$ & $3.35 \pm 0.13^{* \#}$ & $2.07 \pm 0.04^{* \#}$ \\
Tramadol $10 \mathrm{mg} / \mathrm{kg}+$ cannabis $5 \mathrm{mg} / \mathrm{kg}$ & $3.225 \pm 0.11^{* \#}$ & $1.632 \pm 0.04^{+}$ \\
Tramadol $10 \mathrm{mg} / \mathrm{kg}+$ cannabis $10 \mathrm{mg} / \mathrm{kg}$ & $3.52 \pm \pm 0.13^{*+\#}$ & $1.727 \pm 0.03^{*+}$ \\
Tramadol $10 \mathrm{mg} / \mathrm{kg}+$ cannabis $20 \mathrm{mg} / \mathrm{kg}$ & $3.95 \pm 0.21^{*+\#}$ & $1.875 \pm 0.06^{*}$ \\
\hline Units for GFAP, $\mathrm{ng} / \mathrm{l}{ }^{*} p<0.05$ vs. saline control. $+p<0.05$ vs. tramadol (20 mg/kg)-only treated group. \#p $<0.05$ vs. cannabis $(20 \mathrm{mg} / \mathrm{kg})$-only treated group. \\
$\begin{array}{l}\text { Multiple group comparison was done using one-way ANOVA and post hoc Duncan's multiple range test. A probability value of less than } 0.05 \text { was considered } \\
\text { statistically significant }\end{array}$
\end{tabular}

et al. 2007). Therefore, it is suggested that if basal levels of $\mathrm{S} 100 \beta$ in brain extracellular space mediate neuroprotective actions, then a decrease in $S 100 \beta$ in this condition would render neurons vulnerable to changes in extracellular milieu, even to normal levels of oxidative stress. In contrast, under pathological or toxic conditions, in which increased $S 100 \beta$ contributes to neuronal damage, a decrease in this protein by cannabis or $\Delta^{9}$ THC will result in decreased extent of neuronal damage. In support of this notion, the observation that brain S100 $\beta$ was significantly increased after the highest dose of tramadol while the combined treatment with cannabis and tramadol did not result in extensive neurodegeneration as would be anticipated from the effect of either agent alone. It is also suggested that the decrease in $\mathrm{S} 100 \beta$ by cannabis reflects anti-inflammatory effect for the herb. In this context, it should be noted that marijuana has medicinal use in the management of a variety of medical conditions such as multiple sclerosis where an oromucosal spray of the whole plant extract (Sativex) is used to treat spasticity and bladder disorders (Meuth et al. 2015). Cannabis is also being used in epileptic patients (Sulak et al. 2017) and for chronic pain, and fibromyalgia (Aggarwal et al. 2009; Fiz et al. 2011).

The histopathological data proved the neurotoxic effects of cannabis and tramadol. Sections of the cerebral cortex and striatum were examined in view of the effect of cannabis on cognition and motor coordination (D'Souza et al. 2004). Rats treated with cannabis and/or tramadol showed neuronal damage in the form of apoptotic neurons with pyknotic nuclei, shrunken neurons, and focal gliosis. These changes were dose-dependent and consistent with previous observations (Abdel-Salam et al. 2014; Abdel-Salam et al. 2019; Ghoneim et al. 2014). The present study showed that a dose of $5 \mathrm{mg} / \mathrm{kg}$ of cannabis was not enough to produce histopathological

Table 3 The brain and plasma S100 $\mathrm{\beta}$ in cannabis- and/or tramadol-treated rats

\begin{tabular}{lll}
\hline Treatment group & Brain S100ß & Serum S100ß \\
\hline Normal control & $139.7 \pm 5.0$ & $116.5 \pm 5.2$ \\
Cannabis $5 \mathrm{mg} / \mathrm{kg}$ & $109.4 \pm 3.9^{*}$ & $116.3 \pm 6.7$ \\
Cannabis $10 \mathrm{mg} / \mathrm{kg}$ & $107.9 \pm 4.8^{*}$ & $105.97 \pm 4.9$ \\
Cannabis $20 \mathrm{mg} / \mathrm{kg}$ & $113.03 \pm 3.6^{*}$ & $98.9 \pm 3.3^{*}$ \\
Tramadol $5 \mathrm{mg} / \mathrm{kg}$ & $132.2 \pm 4.7$ & $109.7 \pm 4.4$ \\
Tramadol $10 \mathrm{mg} / \mathrm{kg}$ & $153.55 \pm 3.5^{\#}$ & $105.5 \pm 6.5$ \\
Tramadol $20 \mathrm{mg} / \mathrm{kg}$ & $162.5 \pm 3.3^{* \#}$ & $97.85 \pm 3.7^{*}$ \\
Tramadol $10 \mathrm{mg} / \mathrm{kg}+$ cannabis $5 \mathrm{mg} / \mathrm{kg}$ & $102.52 \pm 4.3^{*+}$ & $103.23 \pm 3.1$ \\
Tramadol $10 \mathrm{mg} / \mathrm{kg}+$ cannabis $10 \mathrm{mg} / \mathrm{kg}$ & $114.07 \pm 4.4^{*+}$ & $102.2 \pm 4.2$ \\
Tramadol $10 \mathrm{mg} / \mathrm{kg}+$ cannabis $20 \mathrm{mg} / \mathrm{kg}$ & $101.87 \pm 6.2^{*+}$ & $91.23 \pm 3.7^{*}$ \\
\hline
\end{tabular}

Units for $\mathrm{S} 100 \beta, \mathrm{ng} / \mathrm{l} .{ }^{*} p<0.05$ vs. saline control. $+p<0.05$ vs. corresponding tramadol-only treated group. ${ }^{*} p<0.05$ vs. cannabis (20 mg/kg)-only treated group. Multiple group comparison was done using one-way ANOVA and post hoc Duncan's multiple range test. A probability value of less than 0.05 was considered statistically significant 


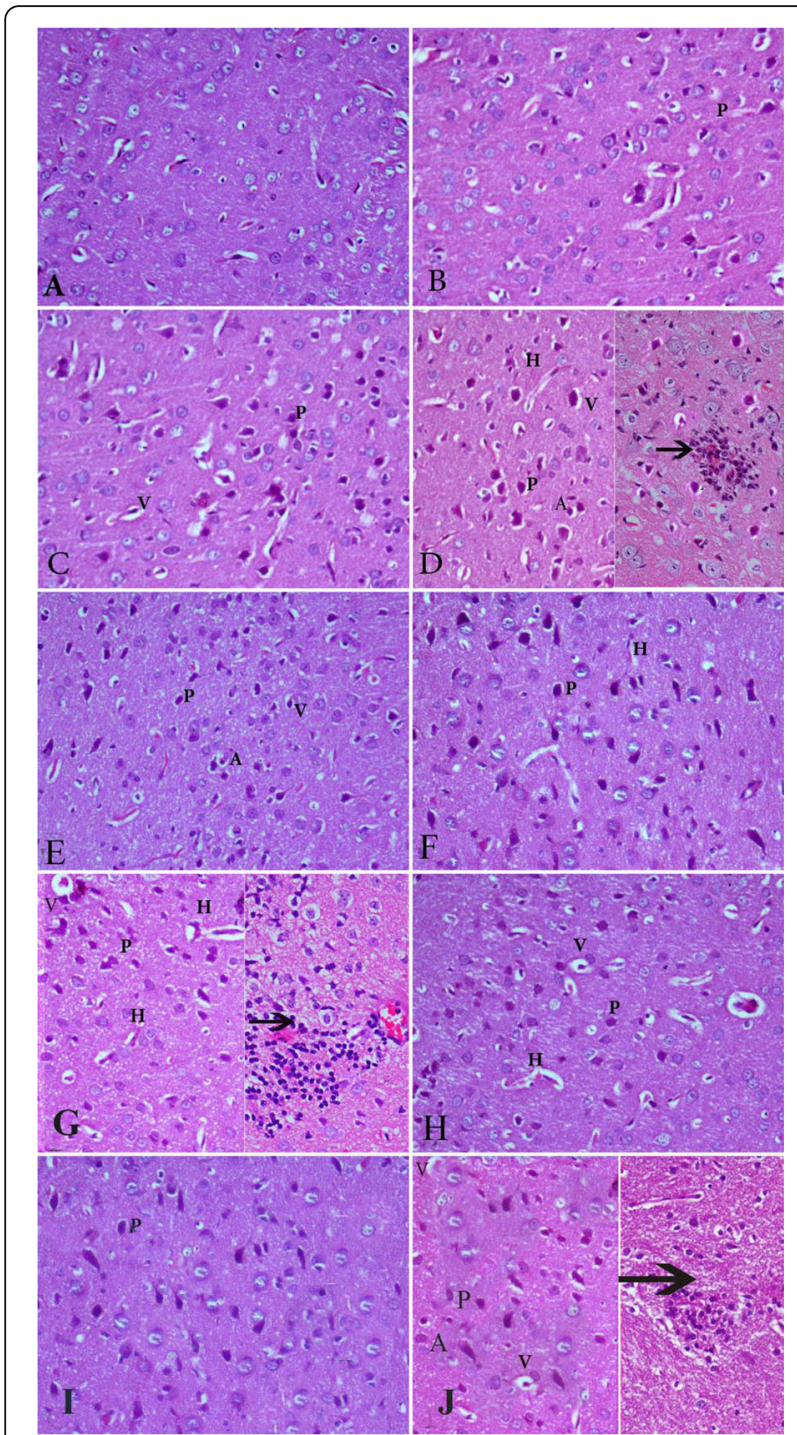

Fig. 4 Representative H\&E stained sections from the cortex of rats treated with a saline; $\mathbf{b}$ cannabis $5 \mathrm{mg} / \mathrm{kg}$ showing pyknotic darkly stained nuclei (P); c cannabis $10 \mathrm{mg} / \mathrm{kg}$ showing cytoplasmic vacuolations $(V)$ and pyknotic darkly stained nuclei (P); $\mathbf{d}$ cannabis 20 $\mathrm{mg} / \mathrm{kg}$ showing (left) cytoplasmic vacuolations (V), pyknotic nuclei $(P)$, and apoptotic cells $(A)$ and (right) hemorrhage $(H)$ and focal gliosis (arrow); e Tramadol $5 \mathrm{mg} / \mathrm{kg}$ showing cytoplasmic vacuolations $(\mathrm{V})$, pyknotic nuclei $(\mathrm{P})$, and apoptotic cells (A); $\mathbf{f}$ Tramadol $10 \mathrm{mg} / \mathrm{kg}$ showing pyknotic nuclei (P) and hemorrhage (H); $\mathbf{g}$ Tramadol 20 mg/kg showing (left) cytoplasmic vacuolations $(\mathrm{V})$, hemorrhage $(\mathrm{H})$, and pyknotic nuclei $(\mathrm{P})$ and (right) mild diffuse gliosis (arrow); h cannabis $5 \mathrm{mg} / \mathrm{kg}$ + tramadol $10 \mathrm{mg} / \mathrm{kg}$ showing cytoplasmic vacuolations $(V)$, pyknotic nuclei $(P)$, and hemorrhage $(\mathrm{H})$; i cannabis $10 \mathrm{mg} / \mathrm{kg}$ + tramadol $10 \mathrm{mg} / \mathrm{kg}$ showing pyknotic nuclei $(P) ; \mathbf{j}$ cannabis $20 \mathrm{mg} / \mathrm{kg}+$ tramadol $10 \mathrm{mg} / \mathrm{kg}$ showing (left) cytoplasmic vacuolations (V), pyknotic nuclei (P), and apoptotic cells (A) and (right) focal gliosis (arrow) (H\&E $\times 400)$

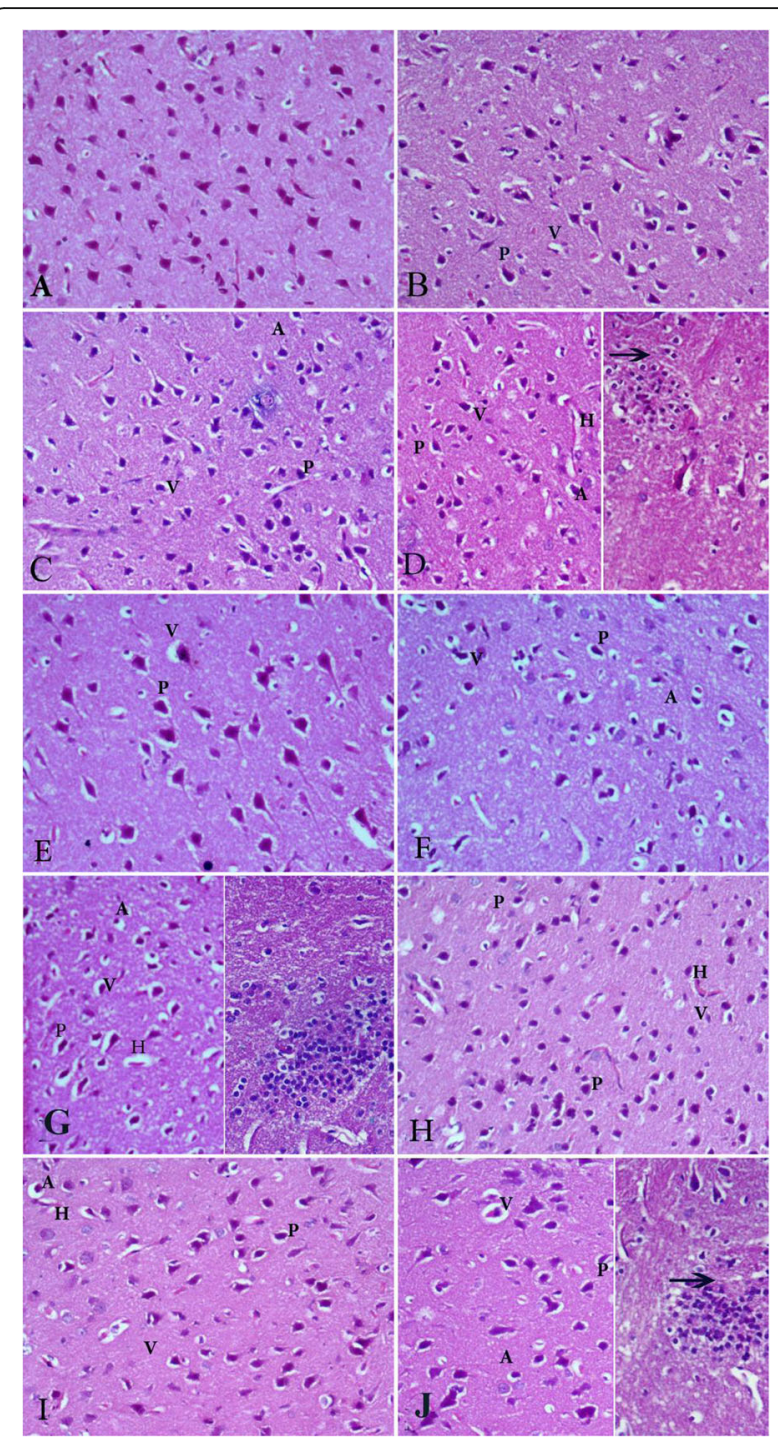

Fig. 5 Representative H\&E stained sections from the striatum of rats treated with a saline; $\mathbf{b}$ cannabis $5 \mathrm{mg} / \mathrm{kg}$ showing cytoplasmic vacuolations $(V)$ and pyknotic darkly stained nuclei $(P) ; c$ cannabis 10 $\mathrm{mg} / \mathrm{kg}$ showing cytoplasmic vacuolations $(\mathrm{V})$, pyknotic nuclei $(\mathrm{P})$, and apoptotic cells (A); $\mathbf{d}$ cannabis $20 \mathrm{mg} / \mathrm{kg}$ showing (left) cytoplasmic vacuolations $(\mathrm{V})$, pyknotic nuclei $(\mathrm{P})$, and apoptotic cells (A) and (right) hemorrhage $(\mathrm{H})$ and focal gliosis (arrow); e tramadol 5 $\mathrm{mg} / \mathrm{kg}$ showing cytoplasmic vacuolations $(\mathrm{V})$ and pyknotic nuclei $(\mathrm{P})$; f tramadol $10 \mathrm{mg} / \mathrm{kg}$ showing cytoplasmic vacuolations $(\mathrm{V})$, pyknotic nuclei (P), and apoptotic cells (A); $\mathbf{g}$ tramadol $20 \mathrm{mg} / \mathrm{kg}$ showing (left) cytoplasmic vacuolations (V), pyknotic nuclei (P), apoptotic cells $(\mathrm{A})$, and hemorrhage $(\mathrm{H})$ and (right) and diffuse gliosis (arrow); $\mathbf{h}$ cannabis $5 \mathrm{mg} / \mathrm{kg}$ + tramadol $10 \mathrm{mg} / \mathrm{kg}$ showing, cytoplasmic vacuolations $(V)$, pyknotic nuclei $(P)$, and hemorrhage $(H)$; i cannabis $10 \mathrm{mg} / \mathrm{kg}$ + tramadol $10 \mathrm{mg} / \mathrm{kg}$ showing cytoplasmic vacuolations (V), pyknotic nuclei (P), and apoptotic cells (A). Hemorrhage $(H) ; \mathbf{j}$ cannabis $20 \mathrm{mg} / \mathrm{kg}$ + tramadol $10 \mathrm{mg} / \mathrm{kg}$ showing (left) cytoplasmic vacuolations (V), pyknotic nuclei (P), and apoptotic cells (A) and (right) and gliosis (arrow) $(H \& E \times 400)$ 
changes in the striatum and cortex. Yet, such dose significantly increased UCH-L1 in the brain tissue, while a significantly increased serum UCH-L1 was recorded only after the highest dose of cannabis $(20 \mathrm{mg} / \mathrm{kg})$. The high doses of cannabis were clearly associated with signs of neuronal degeneration (apoptotic neurons). The increase in brain UCH-L1 after low-dose cannabis therefore suggests that the biomarker could be sensitive or an early indicator of neurotoxicity. On the other hand, the increase in brain GFAP after treatment with 10 or $20 \mathrm{mg} /$ $\mathrm{kg}$ of cannabis and in serum GFAP after $20 \mathrm{mg} / \mathrm{kg}$ of cannabis correlates with the appearance of focal areas of gliosis on brain histopathology.

The study also indicates more neurotoxic effects for tramadol with shrunken neurons and pyknotic nuclei being seen with the lowest dose of the drug, i.e., $5 \mathrm{mg} / \mathrm{kg}$. Higher doses were clearly associated with severe neurodegenerative changes compared with cannabis. Here, $\mathrm{UCH}-\mathrm{L} 1$ increased in the brain after the lowest dose of tramadol while in serum, significantly increased $\mathrm{UCH}-$ L1 was observed after 10 or $20 \mathrm{mg} / \mathrm{kg}$ of tramadol, thereby supporting the notion that $\mathrm{UCH}-\mathrm{L} 1$ could serve as a sensitive or early indicator of neurotoxicity. Moreover, GFAP increased in the brain following 10 or 20 $\mathrm{mg} / \mathrm{kg}$ of tramadol and in the serum after $20 \mathrm{mg} / \mathrm{kg}$ of tramadol together with the development of diffuse gliosis on brain histopathology.

\section{Conclusions}

Repeated cannabis or tramadol administration in rats induces increases in serum levels of UCH-L1 or GFAP and neuronal degeneration. Meanwhile, serum or brain levels of S100 $\beta$ are difficult to be used as an indicator for neurotoxic effects of cannabis or tramadol. The present data suggest that the changes in the level of $\mathrm{UCH}-\mathrm{L} 1$ or GFAP reflect neurotoxicity induced by cannabis or tramadol. The utility of serum UCH-L1 and GFAP as valuable markers or indicators that could reflect neurotoxicity of cannabis and/or tramadol in humans could be recommended for further researches.

\section{Abbreviations}

$\Delta^{9}$-THC: Delta-9-tetrahydrocannabinol; CB1 receptor: Cannabinoid receptor 1; CSF: Cerebrospinal fluid; CT: Computerized axial tomography; ELISA: Enzymelinked immunosorbent assay; GFAP: Glial fibrillary acidic protein; II-1 $\beta$ mRNA: Interleukin-1 beta messenger ribonucleic acid; IL-6: Interleukin-6; NFkB: Nuclear factor-kappaB; S100ß: Glial protein S-100 beta; TNF-a: Tumor necrosis factor-alpha; UCH-L1: Ubiquitin-C-terminal hydrolase-1; UNODC: United Nations Office on Drugs and Crime

\section{Acknowledgements}

Not applicable.

\section{Declarations}

The authors declare that this manuscript is original, has not been published before, and is not currently being considered for publication elsewhere.

\section{Authors' contributions}

All authors contributed equally to the manuscript. All authors have read and approved the final article.

\section{Funding}

This research was supported by the NRC Research Project number 10001004.

\section{Availability of data and materials}

Data will not be shared with public access. Please contact author for data requests.

\section{Ethics approval and consent to participate}

Animal procedures were performed in accordance with the regulations of the Institutional Ethics Committee and followed by the recommendations of the National Institutes of Health Guide for Care and Use of Laboratory Animals (Publication No. 85-23, revised 1985).

\section{Consent for publication}

Not applicable.

\section{Competing interests}

The authors declare that they have no competing interests.

\section{Author details}

'Department of Toxicology and Narcotics, National Research Centre, Tahrir St., Dokki, Cairo, Egypt. ${ }^{2}$ Department of Pharmacology, National Research Centre, Tahrir St., Dokki, Cairo, Egypt. ${ }^{3}$ Department of Medical Biochemistry, National Research Centre, Tahrir St., Dokki, Cairo, Egypt. ${ }^{4}$ Department of Pathology, National Research Centre, Tahrir St., Dokki, Cairo, Egypt.

Received: 7 June 2019 Accepted: 27 September 2019

Published online: 19 November 2019

\section{References}

Abdel-Salam OME, Galal AF, Elshebiney SA, Gaafar AEDM (2017) International aspects of cannabis use and misuse: Egypt. In: Preedy V (ed) Handbook of cannabis and related pathologies: biology, pharmacology, diagnosis, and treatment, 1st Edition. Academic Press, Elsevier Science Publishing Co Inc. pp 505-516.

Abdel-Salam OME, Youness ER, Khadrawy YA, Sleem AA (2016) Acetylcholinesterase, butyrylcholinesterase and paraoxonase 1 activities in rats treated with cannabis, tramadol or both. Asian Pac J Trop Med 9:1066-1071

Abdel-Salam OME, Youness ER, Mohammed NA, Abd El-Moneim OM, Shaffie N (2019) Citicholine protects against tramadol-induced oxidative stress and organ damage. Reactive Oxygen Species 7:106-120

Abdel-Salam OME, Youness ER, Shaffee N (2014) Biochemical, immunological, DNA and histopathological changes caused by Cannabis sativa in the rat. J Neurol Epidemiol 2:6-16

Adami C, Bianchi R, Pula G, Donato R (2004) S100B-stimulated NO production by $\mathrm{BV}$-2 microglia is independent of RAGE transducing activity but dependent on RAGE extracellular domain. Biochim Biophys Acta 1742:169-177

Aggarwal SK, Carter GT, Sullivan MD, ZumBrunnen C, Morrill R, Mayer JD (2009) Characteristics of patients with chronic pain accessing treatment with medical cannabis in Washington State. J Opioid Manag 5:257-286

Bassiony MM, Salah El-Deen GM, Yousef U, Raya Y, Abdel-Ghani MM, El-Gohari H, Atwa SA (2015) Adolescent tramadol use and abuse in Egypt. Am J Drug Alcohol Abuse 41:206-211

Becker B, Wagner D, Gouzoulis-Mayfrank E, Spuentrup E, Daumann J (2010) The impact of early-onset cannabis use on functional brain correlates of working memory. Prog Neuropsychopharmacol Biol Psychiatry 34:837-845

Berge J, Håkansson A, Berglund M (2014) Alcohol and drug use in groups of cannabis users: results from a survey on drug use in the Swedish general population. Am J Addict 23:272-279

Craft JM, Watterson DM, Marks A, Van Eldik L (2005) Enhanced susceptibility of S-100B transgenic mice to neuroinflammation and neuronal dysfunction induced by intracerebroventricular infusion of human beta-amyloid. Glia 51: 209-216

Cutando L, Busquets-Garcia A, Puighermanal E, Gomis-González M, DelgadoGarcía JM, Gruart A, Maldonado R, Ozaita A (2013) Microglial activation underlies cerebellar deficits produced by repeated cannabis exposure. J Clin Invest 23:2816-2831 
D'Souza DC, Perry E, MacDougall L, Ammerman Y, Cooper T, Wu YT, Braley G, Gueorguieva R, Krystal JH (2004) The psychotomimetic effects of intravenous delta-9-tetrahydrocannabinol in healthy individuals: implications for psychosis. Neuropsycho Pharmacol 29(8):1558-1572

Drury RVA, Walligton EA (1980) Carleton's histological technique, 5th edn. Oxford University Press, New York, p 206

El-Hadidy MA, Helaly AM (2015) Medical and psychiatric effects of long-term dependence on high dose of tramadol. Subst Use Misuse 50:582-589

ElSohly MA, Radwan MM, Gul W, Chandra S, Galal A (2017) Phytochemistry of cannabis sativa L. In: Kinghorn AD, Falk H, Gibbons S, Kobayashi J (eds) Phytocannabinoids unraveling the complex chemistry and pharmacology of cannabis sativa. Progress in the Chemistry of Organic Natural Products. Springer International Publishing, Switzerland, pp 1-36

Fiz J, Durán M, Capellà D, Carbonell J, Farré M (2011) Cannabis use in patients with fibromyalgia: effect on symptoms relief and health-related quality of life. PLoS One 6:e18440

French L, Gray C, Leonard G, Perron M, Pike GB, Richer L, Séguin JR, Veillette S, Evans CJ, Artiges E, Banaschewski T et al (2015) Early cannabis use, polygenic risk score for schizophrenia, and brain maturation in adolescence. JAMA Psychiatry 72(10):1002-1011

Ghoneim FM, Khalaf HA, Elsamanoudy AZ, Helaly AN (2014) Effect of chronic usage of tramadol on motor cerebral cortex and testicular tissues of adult male albino rats and the effect of its withdrawal: histological, immunohistochemical and biochemical study. Int J Clin Exp Pathol 7:7323-7341

Glushakova OY, Jeromin A, Martinez J, Johnson D, Denslow N, Streeter J, Hayes RL, Mondello S (2012) Cerebrospinal fluid protein biomarker panel for assessment of neurotoxicity induced by kainic acid in rats. Toxicol Sci 130:158-167

Gong B, Leznik E (2007) The role of ubiquitin C-terminal hydrolase L1 in neurodegenerative disorders. Drug News Perspect 20:365-370

Grond S, Sablotzki A (2004) Clinical pharmacology of tramadol. Clin Pharmacokinet 43(13):879-923

Hooper SR, Woolley D, De Bellis MD (2014) Intellectual, neurocognitive, and academic achievement in abstinent adolescents with cannabis use disorder. Psychopharmacology (Berl) 231:1467-1477

luvone T, Esposito G, De Filippis D, Bisogno T, Petrosino S, Scuderi C, Di Marzo V, Steardo L (2007) Endocannabinoid Research Group. Cannabinoid CB1 receptor stimulation affords neuroprotection in MPTP-induced neurotoxicity by attenuating S100B up-regulation in vitro. J Mol Med (Berl) 85:1379-1392

Kögel D, Peters M, König HG, Hashemi SM, Bui NT, Arolt V, Rothermundt M, Prehn JH (2004) S100B potently activates p65/c-Rel transcriptional complexes in hippocampal neurons: clinical implications for the role of S100B in excitotoxic brain injury. Neuroscience 127:913-920

Laterza OF, Modur VR, Ladenson JH (2008) Biomarkers of tissue injury. Biomark Med 2:81-92

Lewis LM, Schloemann DT, Papa L, Fucetola RP, Bazarian J, Lindburg M, Welch RD (2017) Utility of serum biomarkers in the diagnosis and stratification of mild traumatic brain injury. Acad Emerg Med 24:710-720

Liu L, Li Y, Van Eldik LJ, Griffin WS, Barger SW (2005) S100B-induced microglial and neuronal IL-1 expression is mediated by cell type-specific transcription factors. J Neurochem 92:546-553

Lopez-Rodriguez AB, Llorente-Berzal A, Garcia-Segura LM, Viveros MP (2014) Sexdependent long-term effects of adolescent exposure to THC and/or MDMA on neuroinflammation and serotoninergic and cannabinoid systems in rats. Br J Pharmacol 171:1435-1447

Lorenzetti V, Solowij N, Whittle S, Fornito A, Lubman DI, Pantelis C, Yücel M (2015) Gross morphological brain changes with chronic, heavy cannabis use. Br J Psychiatry 206:77-78

Mannix R, Eisenberg M, Berry M, Meehan WP 3rd, Hayes RL (2014) Serum biomarkers predict acute symptom burden in children after concussion: a preliminary study. J Neurotrauma 31:1072-1075

Meuth SG, Vila C, Dechant KL (2015) Effect of Sativex on spasticity-associated symptoms in patients with multiple sclerosis. Expert Rev Neurother 15(8): 909-918

Nazarzadeh M, Bidel Z, Carson KV (2014) The association between tramadol hydrochloride misuse and other substances use in an adolescent population: phase I of a prospective survey. Addictive Behaviors 39:333-337

O'Callaghan JP, Sriram K (2005) Glial fibrillary acidic protein and related glial proteins as biomarkers of neurotoxicity. Expert Opin Drug Saf 4:433-442
Patro N, Shrivastava M, Tripathi S, Patro IK (2009) S100beta upregulation: a possible mechanism of deltamethrin toxicity and motor coordination deficits. Neurotoxicol Teratol 31:169-176

Ponath G, Schettler C, Kaestner F, Voigt B, Wentker D, Arolt V, Rothermundt M (2007) Autocrine S100B effects on astrocytes are mediated via RAGE. J Neuroimmunol 184:214-222

Ramezani F, Bahrami-Amiri A, Babahajian A, Shahsavari Nia K, Yousefifard M (2018) Ubiquitin C-terminal hydrolase-L1 (UCH-L1) in prediction of computed tomography findings in traumatic brain injury; a meta-analysis. Emerg (Tehran) 6(1):e62

Randall C, Crane J (2014) Tramadol deaths in Northern Ireland: a review of cases from 1996 to 2012. J Forensic Leg Med 23:32-36

Reali C, Pillai R, Saba F, Cabras S, Michetti F, Sogos V (2012) S100B modulates growth factors and costimulatory molecules expression in cultured human astrocytes. J Neuroimmunol 243:95-99

Realini N, Rubino T, Parolaro D (2009) Neurobiological alterations at adult age triggered by adolescent exposure to cannabinoids. Pharmacol Res 60(2):132-138

Roberts RA, Aschner M, Calligaro D, Guilarte TR, Hanig JP, Herr DW, Hudzik TJ, Jeromin A, Kallman MJ et al (2015) Translational biomarkers of neurotoxicity: a health and environmental sciences institute perspective on the way forward. Toxicological Sciences 148(2):332-340

Shivers SC, Newton C, Friedman H, Klein TW (1994) Delta 9-Tetrahydrocannabinol (THC) modulates IL-1 bioactivity in human monocyte/macrophage cell lines. Life Sci 54:1281-1289

Solowij N, Battisti R (2008) The chronic effects of cannabis on memory in humans: a review. Curr Drug Abuse Rev 1:81-98

Stella N (2010) Cannabinoid and cannabinoid-like receptors in microglia, astrocytes, and astrocytomas. Glia 58:1017-1030

Suárez I, Bodega G, Ramos JA, Fernández-Ruiz JJ, Fernández B (2000) Neuronal and astroglial response to pre- and perinatal exposure to delta-9-tetrahydrocannabinol in the rat substantia nigra. Dev Neurosci 22:253-263

Sulak D, Saneto R, Goldstein B (2017) The current status of artisanal cannabis for the treatment of epilepsy in the United States. Epilepsy Behav 70(Pt B):328-333. https://doi.org/10.1016/j.yebeh.2016.12.032

Turner JC, Mahlberg PG (1984) Separation of acid and neutral cannabinoids in cannabis sativa L. using HPLC. In: Agurell S, DeweyWL WRE (eds) The cannabinoids: chemical, pharmacologic, and therapeutic aspects. Academic Press, USA, pp 79-88

Villarreal A, Aviles Reyes RX, Angelo MF, Reines AG, Ramos AJ (2011) S100B alters neuronal survival and dendrite extension via RAGE-mediated NF-KB signaling. J Neurochem 117:321-332

Wadsworth E, Hammond D (2019) International differences in patterns of cannabis use among youth: prevalence, perceptions of harm, and driving under the influence in Canada, England \& United States. Addict Behav 90: $171-175$

World Drug Report 2018 (United Nations publication, Sales No. E.18.XI.9).

Xu KX, Tao J, Zhang N, Wang JZ (2015) Neuroprotective properties of vitamin $C$ on equipotent anesthetic concentrations of desflurane, isoflurane, or sevoflurane in high fat diet fed neonatal mice. Int J Clin Exp Med 8:10444-10458

Yang Z, Wang KKW (2015) Glial fibrillary acidic protein: from intermediate filament assembly and gliosis to neurobiomarker. Trends in Neurosciences 38(6):364-374

Zheng ZM, Specter SC (1996) Delta-9-tetrahydrocannabinol suppresses tumor necrosis factor alpha maturation and secretion but not its transcription in mouse macrophages. Int J Immunopharmacol 18:53-68

Züngün C, Yilmaz FM, Tutkun E, Yilmaz H, Uysal S (2013) Assessment of serum $\mathrm{S} 100 \mathrm{~B}$ and neuron specific enolase levels to evaluate the neurotoxic effects of organıc solvent exposure. Clin Toxicol (Phila) 51:748-751

\section{Publisher's Note}

Springer Nature remains neutral with regard to jurisdictional claims in published maps and institutional affiliations. 